\title{
Study of Forming Factors Electronic Word of Mouth (EWOM) and Its Influence On Purchasing Fruit Products at Kojama Shop
}

\author{
Siti Suciani Fitriah ${ }^{1 *}$, Budi Dharmawan ${ }^{2}$, Ulfah Nurdiani ${ }^{3}$ \\ Departement of Agribusiness, Faculty of Agriculture, Jenderal Soedirman University \\ Received: 5 August 2020; Revised: 8 October 2021; Accepted: 15 October 2021
}

\begin{abstract}
Kojama Shop is an online platform that markets avocado butter products. To win the competition, Kojama Shop must improve Electronic Word of Mouth (eWOM) by knowing the factors that form eWOM and their effect on purchases. This study aims to determine the factors that form eWOM on the purchase of fruit products at the Kojama Shop and the influence of the factors formed from eWOM on the purchase of fruit products at the Kojama Shop. The selection of research places is intentional. The target of research is the follower of the Kojama Shop Instagram account that has already bought and consumed butter avocado fruit products at least 2 times, aged at least 18 years, and actively using social media Instagram. Data retrieval using survey methods through online questionnaires using Google forms. Sampling using the Unknown Population formula, the study took 151 respondents. Data analysis uses descriptive and multiple linear regression. The results showed that there are 5 factors of eWOM: Concern for Others, Expressing Positive Feelings, Economic Incentives, Helping the Company, and Platform Assistance. These five factors have a significant influence together and an individual towards the purchase.
\end{abstract}

Keywords: fruit; purchasing; multiple; linear; regression

\section{How to cite:}

Fitriah, S. S., Dharmawan, B., \& Nurdiani, U. (2021). Study of Forming Factors Electronic Word of Mouth ( EWOM ) and Its Influence On Purchasing Fruit Products at Kojama Shop. Habitat, 32(3), 119-129. https://doi.org/10.21776/ub.habitat.2021.032.3.14

\section{Introduction}

Technology and information have developed very rapidly with the use of the internet in the marketing process, making it easier for users to interact with each other (Cahyono, 2016). This benefits businesspeople because it allows information to be delivered quickly, with a broad reach, and at a low cost. According to Evans and MvKee (2010) in Rachmalika (2015) before purchasing a product, consumers can also benefit from the experiences of others.

Someone can share their product-related experiences with other customers. This type of communication is commonly referred to as Word of Mouth (WOM). Word of Mouth (WOM) is a type of communication that has spread to the electronic world and is known as Electronic Word of Mouth (eWOM). According to Thurau et.al (2004) a positive or negative statement

\footnotetext{
*) Correspondence Author.

E-mail: sitisuciani@gmail.com
}

formed from the opinions of consumers, prospective consumers, and former consumers of a product that can be accessed by a large audience in cyberspace is referred to as eWOM. According to Jeong (2011) positive eWOM manifests itself in three dimensions: Concern for Others, Expressing Positive Feelings and Helping the Company. Meanwhile, Thurau et al. (2004) discovered eight dimensions of eWOM that can influence consumers, namely: Platform Assistance Venting Negative Feelings, Concern for Others, Extraversion/ Positive SelfEnhancement, Social Benefit, Economic Incentives, Helping the Company and Advice Seeking.

Electronic Word of Mouth (eWOM) has several advantages over traditional Word of Mouth (WOM), including low cost, high speed, and the effect of externalities. The consumer's decision to purchase a product is heavily influenced by the opinion of a trusted person about the product delivered, rather than the opinion of the company's advertising (Sari, 2012). According to Sari (2012), online user reviews influence other users' perceptions of the 
product, which can be categorized as eWOM. Potential influencers are an important component of eWOM because they can influence the perception of other consumers to make purchases through online product reviews and help companies improve the effectiveness of their online marketing strategies.

Kojama Shop is a company that markets through social media and makes it easier for customers to obtain high-quality fruits. To interact with their customers, Kojama Shop has an Instagram account with id @kojamashop. According to a preliminary survey conducted in November 2019, Kojama Shop has the most followers, 117,000, when compared to similar accounts, indicating that there is a lot of availability from someone to learn more about avocado butter at Kojama Shop. Kojama Shop conducts sales transactions with the Kojama Shop id on the Go-Send, Grab, and Shopee marketplaces. To get closer to their customers, Kojama Shop has a tagline with the hashtags \#stayhealthywithkojama and \#enjoyours. Kojama Shop has an office in Cakung, East Jakarta, and uses online marketing to serve sales throughout Indonesia, one of which is the Instagram social media platform. Followers of the @kojamashop account actively review, update, recommend, or simply share their experiences. Instagram social media can lead to social interaction, which promotes the creation of eWOM and establishes Kojama Shop as a new phenomenon among Indonesian fruit lovers.

Regular premium quality avocado butter and jumbo quality avocado butter are available at Kojama Shop. Kojama Shop sources its avocados from farmers in Indonesian provinces ranging from Lampung, Probolinggo, Garut and NTB. Products are marketed in the Jabodetabek area with delivery via go send, and shipping outside of Jabodetabek is handled by expeditions. Because technological advancements and the passage of time have resulted in product competition (Cahyono, 2016), Kojama Shop must have the best strategy to attract customers to purchase their products and can influence product sales at Kojama Shop. Besides that, today's consumers are astute and critical. Before purchasing a product, consumers can obtain a variety of information, looking for information in a variety of ways, such as asking friends via the internet, and not easily believing what the company or sales representative doing the promotion says.
A brand, product, service, or company is meaningless if it can't be a topic of conversation among consumers (Rachmalika, 2015). The spread of eWOM on social media has made the Kojama Shop phenomenon a hotly debated topic. Satisfied customers will tell and recommend the fruit products of Kojama Shop, which will eventually spread to all people and all walks of life. This is the context for the study titled " Study of Forming Factors Electronic Word of Mouth (EWOM) and Its Influence On Purchasing Fruit Products at Kojama Shop"

\section{Theoretical Underpinning}

Social media sites are regarded as suitable eWOM platforms (Canhoto and Clark, 2013; Erkan and Evans, 2016; Kim et al., 2014). EWOM is one of the factors that can influence consumer purchases. According to Chevalier and Mayzlin (2006) and Huyen and Costello (2017), the number of reviews or comments posted online about a product or service indicates its popularity. Furthermore, the amount of information that someone shares are one of the factors that can help others make a purchasing decision. To win the competition, Kojama Shop must improve eWOM by understanding the factors that contribute to eWOM and their impact on consumer purchases.

Age, gender, formal education, type of work, income, use of social media, product purchases, and consumption can all be used to identify consumer characteristics. The obtained data for the characteristics of Kojama Shop consumers are analyzed using descriptive analysis by grouping consumers who have the same answer and then calculating a percentage for each category. According to Sakti (2018) research on the relationship between consumer characteristics and the factors considered when purchasing organic vegetables at the Bogor Convenience Store, consumer characteristics can influence consumer purchases.

According to Jeong (2011) research, which focuses on the positive eWOM dimension, the positive eWOM dimension can be seen through three dimensions, namely: 1 . Concern for Others 2. Expressing Positive Feelings 3. Helping The Company. Thurau et al. (2004) discovered eight dimensions of eWOM that can affect consumers in his research, namely: 1. Platform Assistance 2. Venting Negative Feelings 3. Concern for Others 4. Extraversion / Positive Self-Enhancement 5. Social Benefits 6. Economic Incentives 7. 
Helping The Company 8. Advice Seeking. In this study, the researcher used not only one study as a reference but also two studies (Jeong, 2011; and Thurau, 2004) that had developed. As a result of the two previous studies, the researcher developed five dimensions, namely: Concern for Others, Expressing Positive Feelings, Economic Incentives, Helping the Company, and Platform Assistance.

Before conducting data analysis, it is necessary to conduct validity and reliability tests on the data obtained by the authors to obtain valid research data. In determining the factors that comprise eWOM, a Likert scale is used as a measuring instrument. The eWOM factors that influence purchase will be tested to see if they influence consumer behavior when purchasing a product. A purchase is a consumer's behavior. According to (Lee and Turban, 2001) and (Jun, M., Yang, Z., and Kim, D. 2004), product purchases are measured by the following indicators: (1) A high level of trust in the company where you work. (2) Having a quality product, (3) Having good service quality, and (4) The price offered is following the product are all important factors in times of uncertainty and risk.

The obtained data were then subjected to multiple linear regression analysis to determine the factors that influence the purchase of fruit products at Kojama Shop. According to Racmhalika (2015) study on the factors forming Electronic Word of Mouth and its influence on purchasing decisions at the Hakata Ikkousha restaurant in Jakarta discovered three factors: Expressing Positive Feelings, Platform Assistance, and Concern for Other Factors. These three factors have a significant impact on purchasing decisions, both jointly and individually. The author expects the output or results to be material for consideration as well as a source of information and recommendations for the Kojama Shop company to improve eWOM in order to compete with other products.

\section{Research Methods}

This research was conducted at the Kojama Shop in Cakung, East Jakarta. The Kojama Shop Instagram account is where the data is collected. The research site was chosen with care, taking into account that the Kojama Shop Instagram account had the most followers when compared to other similar accounts. The research was conducted from March 6 to April 21, 2020. Based on the Unknown Population formula, 151 people were included in this research (Riduwan and Akdon, 2013). Non-probability sampling with incidental sampling techniques was used in this study (Sugiyono, 2018). The chosen respondents are Instagram followers of the Kojama Shop who have purchased and consumed avocado butter products at least twice, are at least 18 years old, and actively use the Instagram social media platform.

The data used are primary and secondary, both quantitative and qualitative. Primary data were collected from respondents who completed questionnaires via Google Forms, namely data on consumer characteristics of avocado butter products and attitudes related to Electronic Word of Mouth (eWOM) factors when purchasing fruit products at Kojama Shop. The eWOM factors are measured using score indicators ranging from research findings to consumer feedback. A Likert scale is used to evaluate the score. According to Sugiyono (2018), the Likert scale is used to assess a person's or group's attitudes, opinions, and perceptions of social phenomena. On the Likert scale, each instrument item has a positive and negative score. According to Sugiyono (2018), the questionnaire score is determined as follows:

Table 1. Likert Scale Category

\begin{tabular}{lll}
\hline No & Statement & Score \\
\hline 1. & Strongly Agree & 5 \\
2. & Agree & 4 \\
3. & Neutral & 3 \\
4. & Disagree & 2 \\
5. & Strongly Disagree & 1 \\
\hline
\end{tabular}

The variables used in this study are as follows:

1. Purchase refers to the reason why someone prefers, selects, and purchases a product.

2. Concern for Others is a genuine desire to advise other consumers on how to buy products or services correctly.

3. Expressing Positive Feelings is the act of expressing positive feelings that are triggered by positive consumption experiences.

4. Economic Incentives refer to the desire to receive financial incentives from Kojama Shop.

5. Helping the Company is the result of consumer satisfaction with the product and the subsequent interest in helping the company in exchange for the company's continued success. 
6. Platform Assistance refers to consumer trust in the platform in question, namely Instagram.

\subsection{Instrument Test Methods}

\section{a. Validity and Reliability Test}

A validity test is a step in which the content of an instrument is tested to determine the accuracy of the instrument used in a study (Sugiyono, 2018). The results of Corrected Item Total Correlation are obtained by using the value of $r$. If $r_{\text {count }} \geq r_{\text {table }}$, then the collected data is declared valid. The consistency of scores obtained by the same person when retested with the same test on different occasions, with a different set of equivalent items, or under different test conditions is referred to as test reliability (Anastasia and Susana, 1997). Cronbach's alpha was used to calculate the reliability of each variable. If Cronbach's Alpha > 0.60 , the reliability is very high.

\subsection{Data Analysis Methods}

\section{a. Descriptive Analysis}

Descriptive analysis is employed to provide an empirical or descriptive description of the study's data (Augusty, 2006). Descriptive analysis is used to gain a better understanding of consumer characteristics as well as the findings of the eWOM analysis and their impact on fruit purchases at Kojama Shop.

\section{b. Multiple Linear Regression Analysis}

Multiple linear regression analysis is a technique for determining the effect of two or more independent variables on one dependent variable. The dependent variable and each of its predictors are assumed to have a one-line or linear relationship in this model (Janie, 2012).

The model design that will be proposed is a multiple linear regression model with five independent variables. The independent variables used are Concern for Others, Expressing Positive Feelings, Economic Incentives, Helping the Company, and Platform Assistance on one dependent variable, namely purchase. Based on the available data, the regression equation used is as follows:

$\mathrm{Y}=\mathrm{a}+\mathrm{b}_{1} \mathrm{X}_{1}+\mathrm{b}_{2} \mathrm{X}_{2}+\mathrm{b}_{3} \mathrm{X}_{3}+\mathrm{b}_{4} \mathrm{X}_{4}+\mathrm{b}_{5} \mathrm{X}_{5}+\mathrm{e}$ Where:

Y : Purchase

$\mathrm{X}_{1} \quad$ : Concern for Others

$\mathrm{X}_{2} \quad$ : Expressing Positive Feelings

$\mathrm{X}_{3} \quad$ : Economic Incentives

$\mathrm{X}_{4} \quad$ : Helping the Company
$\mathrm{X}_{5} \quad$ : Platform Assistance

A : Constant

b1-b5 : Regression Coefficient

e : Error

Coefficient of Determination $\left(\mathrm{R}^{2}\right)$

Coefficient of determination is a tool for determining how well the model can explain the variation in the dependent variable. (Ghozali, 2012).

\section{Hypothesis Test}

The data obtained from the research results are processed based on the type of data obtained and then presented in the form of tables and statistical methods that use simultaneous testing (F-test) and partial testing (t-test).

Simultaneous Test (F-test)

The F statistical test determines whether all independent variables or independent variables in the model have a joint effect on the dependent variable or certain variables (Ghozali, 2012). This hypothesis is being tested using F-statistics, and the decision-making criteria used in the Ftest are as follows:

a. If $\mathrm{F}_{\text {count }}>\mathrm{F}_{\text {table }}$ at a significance level of $5 \%$ $(\alpha=0,05), H_{0}$ is rejected or $H_{a}$ is accepted, indicating that the independent variables have a significant effect on the dependent variable together.

b. If $\mathrm{F}_{\text {count }}<\mathrm{F}_{\text {table }}$ at a significance level of $5 \%$ $(\alpha=0,05), H_{0}$ is accepted or $H_{a}$ is rejected, indicating that the independent variables have no effect on the dependent variable together.

Partial Test (t-test)

According to Ghozali (2012), a partial test (t-test) is used to determine how far the independent variables used in this study explain the dependent variable individually. The basis for making decisions used in the t-test are as follows:

1) If $t_{\text {count }}>t_{\text {table }}$ at a significance level $5 \%(\alpha=$ $0,05)$ at a significance level of $5 \%(\alpha=0,05)$, $\mathrm{H}_{0}$ is rejected or $\mathrm{H}_{\mathrm{a}}$ is accepted, indicating that the independent variables have significant effect on the dependent variable individually.

2) If $t_{\text {count }}<t_{\text {table }}$ at a significance level $5 \%(\alpha=$ $0,05), \mathrm{H}_{0}$ is accepted or $\mathrm{H}_{\mathrm{a}}$ is rejected, indicating that the independent variables have no significant effect on the dependent variable individually. 


\section{Result and Discussion}

\subsection{Characteristics of Respondents}

The characteristics of the respondents were obtained from the answers of 151 Kojama Shop consumers. These characteristics are obtained from various criteria as follows:

\section{a. Gender}

Respondents included 127 women and 24 men, indicating that the majority of Kojama Shop customers were female. This is because, according to Harimurti's (2016) research, women are more likely than men to make purchasing decisions in the home. According to Harimurti's (2016) research, women make decisions about basic family needs because they are more involved in purchasing products than men.

\section{b. Age Range}

The age range of the respondents is quite wide, ranging from 15-54 years. A total of 9 respondents ranged in age from 15 -19 years. There were 49 respondents between the ages of 20-24. As many as 48 respondents were between the ages of 25-29. As many as 33 respondents were between the ages of 30-34. As many as 10 respondents were between the ages of 35-39. As many as 1 respondent was between the ages of 40 -44 . While 1 respondent was between the ages of 50-54. Due to the presence of Kojama Shop on online platforms and the main marketing of Kojama Shop is on Instagram, the majority of consumers are at the age level of 20-24 years, where the second highest Indonesian internet penetration is in the age range of 20-24 years, which reached $88.5 \%$ (APJII, 2018).

c. Education Level

The respondent's level of education is determined by the last educational level attained. The majority of the respondents, 71 in total, are S1 graduates. 7 respondents received a master's degree, 14 received a diploma, 57 received a high school diploma, 2 received a junior high diploma, and none received an elementary school diploma. The majority of Kojama Shop respondents had the last education level of S1, which is one of the levels of education with the highest internet penetration (85.1\%) (APJII, 2018). Furthermore, in the second order, the majority of the buyers 57 respondents are high school graduates, which is due to the location of the Kojama Shop being in the Jakarta area and the majority of buyers being in the Jabodetabek area, where products are easily accessible. Other respondents made purchases at the Kojama Shop because the avocado butter product was seen as reasonable in terms of price and quality, and it contained healthy fats, making it suitable for healthy living and dieting.

\section{d. Type of Work}

The respondents' occupations varied, but private employees dominated. There were 63 respondents who worked as private employees. Civil servants account for 7 respondents, entrepreneurs account for 17, housewives account for 21, students account for 38 respondents, BUMN employees account for 1, tutors account for 1 , honorary accounts for 1 , and 2 respondents have not worked. According to the study's findings, the majority of Kojama Shop's customers are private employees, with as many as 63 respondents and 38 students. This is because the majority of Kojama Shop customers live in the Jabodetabek area, where many buyers and can make deliveries via Go-Send/Grab.

\section{e. Average Income}

The average income of the majority of respondents ranges between Rp. 3.000.000-Rp. 8.000.000. While respondents with an average income $<\mathrm{Rp} 1.000 .000$ are represented by 21 respondents, respondents with an average income of $\mathrm{Rp} 1.000 .000-\mathrm{Rp} 3.000 .000$ are represented by 33 respondents, respondents with an average income of Rp3.000.100-Rp5.000.000 are represented by 34 respondents, respondents with an average income of Rp5.000.100-Rp8.000.000 are represented by 27 respondents, and the remaining 36 respondents have an average income of $>$ Rp8.000.000. Kojama Shop customers have a relatively high average income, owing to the store's location in DKI Jakarta, which has the highest UMP in Indonesia at Rp3,940,973 (Pergub Prov. DKI Jakarta.No 114, 2019).

\subsection{Factors Influencing Fruit Product Purchases at Kojama Shop 4.2.1 Multiple Linear Regression Analysis}

Multiple linear regression analysis is a technique for determining the effect of two or more independent variables on one dependent variable. The dependent variable and each of its predictors is assumed to have a one-line or linear relationship in this model (Janie, 2012). The independent variables in this test are Concern for Others, Expressing Positive Feelings, Economic 
Incentives, Helping the Company, and Platform Assistance on one dependent variable, namely purchase of fruit products at the Kojama Shop, as shown in Table 2.

Table 2. Result of Multiple Linear Regression Test

\begin{tabular}{llccccc}
\hline \multirow{2}{*}{ Model } & \multicolumn{2}{c}{$\begin{array}{c}\text { Unstandardized } \\
\text { Coefficients }\end{array}$} & $\begin{array}{c}\text { Standardized } \\
\text { Coefficients }\end{array}$ & T & Sig. \\
\cline { 2 - 6 } & \multicolumn{1}{c}{ B } & Std. Error & Beta & & \\
\hline $1 \quad$ (Constant) & 1.866 & .896 & & 2.082 & .039 \\
Concern for Others & .381 & .115 & .233 & 3.313 & .001 \\
Expressing Positive Feelings & -.382 & .137 & -.302 & -2.788 & .006 \\
Economic Incentives & .595 & .139 & .486 & 4.275 & .000 \\
Helping the Company & .603 & .099 & .396 & 6.058 & .000 \\
Platform Assistance & .208 & .096 & .139 & 2.179 & .031 \\
\hline
\end{tabular}

Based on the results of Multiple Linear Regression Test can be written into the regression model as follows:

$$
\begin{aligned}
& \mathrm{Y}=\mathrm{a}+\mathrm{b}_{1} \mathrm{X}_{1}+\mathrm{b}_{2} \mathrm{X}_{2}+\mathrm{b}_{3} \mathrm{X}_{3}+\mathrm{b}_{4} \mathrm{X}_{4}+\mathrm{b}_{5} \mathrm{X}_{5}+\mathrm{b}_{\mathrm{n}} \mathrm{X}_{\mathrm{n}} \\
& +\ldots . . \text { e (Janie, 2012) } \\
& \text { Purchase }=1,866+0,381 \mathrm{X}_{1}-0,383 \mathrm{X}_{2}+0,595 \mathrm{X}_{3} \\
& +0,603 \mathrm{X}_{4}+0,208 \mathrm{X}_{5}+\mathrm{e}
\end{aligned}
$$

(Primary Research Data, 2020)

\subsubsection{Coefficient of Determination $\left(R^{2}\right)$}

Coefficient of determination is a tool for determining how well the model can explain the variation in the dependent variable. (Ghozali, 2012). Table 3 shows the value of the coefficient of determination.

Table 3. Result of Coefficient of Determination

\begin{tabular}{ccccc}
\hline Model & R & $\begin{array}{c}\text { R } \\
\text { Square }\end{array}$ & $\begin{array}{c}\text { Adjusted } \\
\text { R Square }\end{array}$ & $\begin{array}{c}\text { Std. Error } \\
\text { of the } \\
\text { Estimate }\end{array}$ \\
\hline $1 \quad .847^{\mathrm{a}}$ & .717 & .707 & 1.902662 \\
\hline
\end{tabular}

Based on the results of Coefficient of Determination, the value of an in $\mathrm{R}$ is a constant. The number $\mathrm{R}$ demonstrates a 0.847 double correlation between the variables Concern for Others, Expressing Positive Feelings, Economic Incentives, Helping the Company, and Platform Assistance when purchasing fruit products at the Kojama Shop. $\mathrm{R}$ Square $\left(\mathrm{R}^{2}\right)$ yields a value of 0.717. This figure shows the magnitude of the influence of the Concern for Others, Expressing Positive Feelings, Economic Incentives, Helping the Company, and Platform Assistance variables on the purchase of fruit products at the Kojama Shop by $71.7 \%$, while the remaining $28.9 \%$ of the independent variables provide almost all of the information required. An $\mathrm{R}^{2}$ value close to one indicates that the variable predicts the purchase of fruit products at Kojama Shop.

\subsubsection{Simultaneous Test (F-test)}

The F statistical test determines whether all independent variables or independent variables in the model have a joint effect on the dependent variable or certain variables (Ghozali, 2012). The F test criteria and significance are used as the basis for decision making in testing this hypothesis:

a) If $\mathrm{F}_{\text {count }}>\mathrm{F}_{\text {table }}$ at a significance level of $5 \%$ $(\alpha=0,05), H_{0}$ is rejected or $H_{a}$ is accepted, indicating that the independent variables have a significant effect on the dependent variable together

b) If $\mathrm{F}_{\text {count }}<\mathrm{F}_{\text {table }}$ at a significance level of 5\% $(\alpha=0,05), H_{0}$ is accepted or $H_{a}$ is rejected, indicating that the independent variables have no effect on the dependent variable together.

Hypothesis

$\mathrm{H}_{0}$ : There is no significant influence between the factors forming eWOM on the purchase of fruit products at Kojama Shop.

$\mathrm{H}_{\mathrm{a}}$ : There is significant influence between the factors forming eWOM on the purchase of fruit products at Kojama Shop.

Table 4 shows the results of testing the hypothesis together using the F-test. 
Table 4. Result of Simultaneous Test (F-test)

\begin{tabular}{llccccc}
\hline \multicolumn{1}{c}{ Model } & Sum of Squares & df & Mean Square & F & Sig. \\
\hline 1 & Regression & 1331.267 & 5 & 266.253 & 73.548 & $.000^{\mathrm{a}}$ \\
& Residual & 524.918 & 145 & 3.620 & & \\
& Total & 1856.185 & 150 & & & \\
\hline
\end{tabular}

Based on the results of Simultaneous Test (F-test), the quotient of mean square regression and mean square residual has an $F_{\text {count }}$ value of 73,548 . F $F_{\text {tabel }}$ value with $\mathrm{df}$ regression 5 as $\mathrm{df}$ numerator and residual $\mathrm{df} 145$ as df denominator, so that $\mathrm{F}_{\text {table }}$ with $\alpha=5 \%$ is 2,28 . Because $\mathrm{F}_{\text {count }}$ is greater $\mathrm{F}_{\text {table }}$ which is 2.28 , it can be concluded that the variables Concern for Others, Expressing Positive Feelings, Economic Incentives, Helping the Company, and Platform Assistance in the model have a significant impact on the variable of purchasing fruit products at Kojama Shop. This is also indicated by a significance value of 0.000 , which is less than $\alpha(0,05)$, indicating that $\mathrm{H}_{0}$ is rejected and $\mathrm{H}_{\mathrm{a}}$ is accepted, indicating that the factors forming eWOM have a significant influence on the purchase of fruit products at Kojama Shop.

\subsubsection{Partial Test (t-test)}

According to Ghozali (2012), a partial test (t-test) is used to determine how far the independent variables used in this study explain the dependent variable individually. There are five hypotheses to be tested in this study. The ttest value and the significance value from table 4 of the regression results are used in the test. The basis for the acceptance of a hypothesis is the ttest criteria and significance as follows:

a. If $\mathrm{t}_{\text {count }}>\mathrm{t}_{\text {table }}$ at a significance level $5 \%(\alpha=$ $0,05)$ at a significance level of $5 \%(\alpha=$ $0,05), \mathrm{H}_{0}$ is rejected or $\mathrm{H}_{\mathrm{a}}$ is accepted, indicating that the independent variables have significant effect on the dependent variable individually.

b. If $t_{\text {count }}<t_{\text {table }}$ at a significance level $5 \%(\alpha=$ $0,05), \mathrm{H}_{0}$ is accepted or $\mathrm{H}_{\mathrm{a}}$ is rejected, indicating that the independent variables have no significant effect on the dependent variable individually.

According to Table 5, there are five hypotheses to be tested, which are as follows: Concern for Others $\left(\mathrm{X}_{1}\right)$, Expressing Positive Feelings $\left(\mathrm{X}_{2}\right)$, Economic Incentives $\left(\mathrm{X}_{3}\right)$, Helping the Company $\left(\mathrm{X}_{4}\right)$ and Platform Assistance $\left(\mathrm{X}_{5}\right)$.

Table 5. Result of Partial Test (t-test)

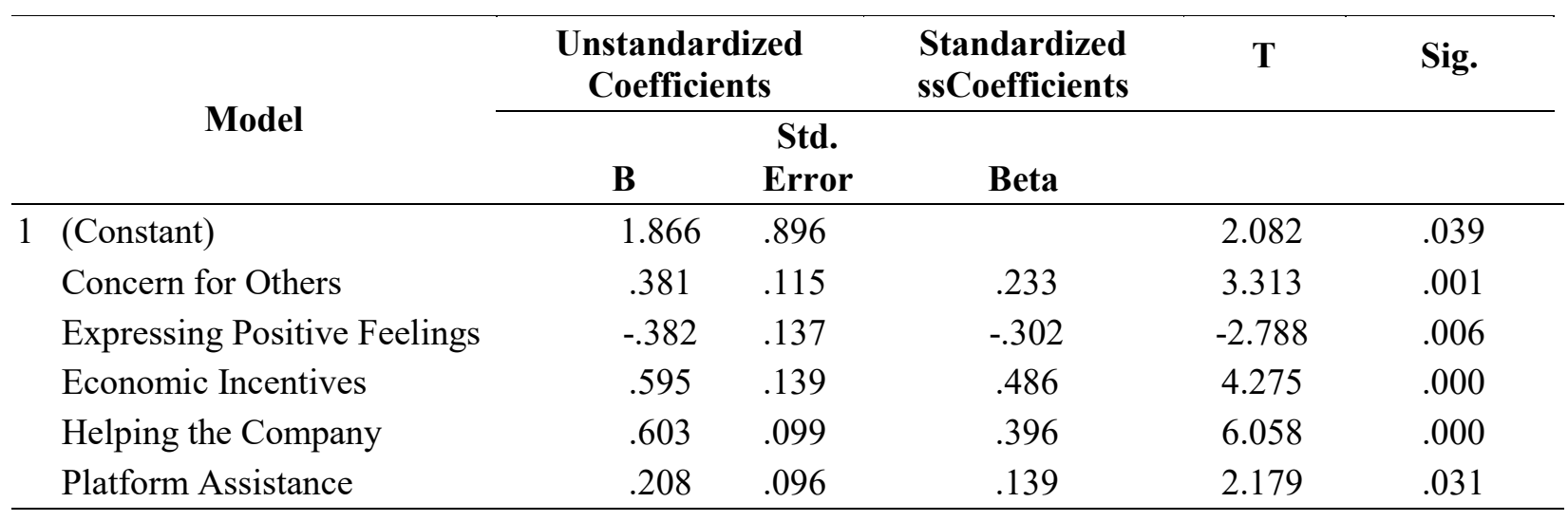

The research hypothesis is as follows:

1) The relationship between Concern for Others (X1) and fruit purchases at the Kojama Shop (Y).

$\mathrm{H}_{0}$ : Concern for Others (X1) has no significant impact on fruit purchases at the Kojama Shop (Y).

$\mathrm{H}_{\mathrm{a}}$ : Concern for Others (X1) has a significant impact on fruit purchases at the Kojama Shop (Y).

$\mathrm{T}_{\text {count }}=3,313>\mathrm{t}_{\text {table }}=1,655(\mathrm{df}=145$, $\alpha=0,05) . H_{0}$ is then rejected, while $\mathrm{H}_{\mathrm{a}}$ is accepted. As a result, the Concern for Others variable individually has a significant effect on the variable of purchasing fruit products at Kojama 
Shop. According to these findings, the greater one's concern for providing information and recommendations to others, the greater one's purchase of fruit products at the Kojama Shop. This study's findings are consistent with previous research (Rachamalika, 2015), which found that the Concern for Others variable had a positive and significant effect on purchases. The presence of posts about fruit products on the Kojama Shop Instagram account can broaden consumer information, making it more trustworthy and appealing. Concern for Others, according to Thurau et al (2004), is a concern or desire to help others make purchasing decisions, either by providing recommendations or by preventing others from consuming a product or service, and this motive is very important in the marketing industry.

2) The relationship between Expressing Positive Feelings $\left(\mathrm{X}_{2}\right)$ and fruit purchases at the Kojama Shop (Y).

$\mathrm{H}_{0}$ : Expressing Positive Feelings $\left(\mathrm{X}_{2}\right)$ has no significant impact on fruit purchases at the Kojama Shop (Y).

$\mathrm{H}_{\mathrm{a}}$ : $\quad$ Expressing Positive Feelings $\left(\mathrm{X}_{2}\right)$ has a significant impact on fruit purchases at the Kojama Shop (Y).

$\mathrm{T}_{\text {count }}=2,788>\mathrm{t}_{\text {table }}=1,655(\mathrm{df}=145$, $\alpha=0,05) . H_{0}$ is then rejected, while $H_{a}$ is accepted. As a result, the Expressing Positive Feelings variable individually has a significant effect on the variable of purchasing fruit products at Kojama Shop. Based on the results of the questionnaire related to consumer pride because they have eaten fruit products from Kojama Shop that are different from other shops with good prices and quality, it produces a positive impression, the stronger the positive impression about Kojama Shop spreads through social media Instagram and the stronger understanding of consumers or potential consumers regarding the positive impression, then consumers automatically spread eWOM because they have eaten fruit products from Kojama Shop that are different from other shops with good prices and quality. These findings are consistent with previous research (Rachmalika, 2015), which found that Expressing Positive Feelings had a significant influence on food purchases at the Hakataikkousha Jakarta restaurant, where every consumer will automatically spread eWOM if they are satisfied with the service and food they consume at a restaurant that provides a positive impression. Kojama Shop customers make purchasing decisions based on positive experiences shared by customers on Instagram. Positive experiences shared by consumers on social media platforms such as Instagram can be truly understood by other consumers and can contribute positive information to others in order for them to make purchasing decisions. According to Wien and Olsen (2014), consumers have a high proclivity to share consumption experiences, and consumers who are satisfied with the products or services consumed are more likely to express positive feelings or experiences. This is also supported by Tseng et al. (2013)'s research, which found that positive eWOM has a significant positive effect on consumer purchase intentions.

3) The relationship between Economic Incentives $\left(\mathrm{X}_{3}\right)$ and fruit purchases at the Kojama Shop (Y).

$\mathrm{H}_{0}$ : Economic Incentives $\left(\mathrm{X}_{3}\right)$ has no significantimpact on fruit purchases at the Kojama Shop (Y).

$\mathrm{H}_{\mathrm{a}}$ : Economic Incentives $\left(\mathrm{X}_{3}\right)$ has a significantimpact on fruit purchases at the Kojama Shop (Y).

$\mathrm{T}_{\text {count }}=4,275>\mathrm{t}_{\text {table }}=1,655(\mathrm{df}=145$, $\alpha=0,05) . H_{0}$ is then rejected, while $H_{a}$ is accepted. As a result, the Economic Incentives variable individually has a significant effect on the variable of purchasing fruit products at Kojama Shop.This result means that if the Economic Incentives perceived or obtained by consumers are higher, the consumer's decision to buy fruit products at Kojama Shop will also be higher. These findings are consistent with previous research (Hasan and Setiyaningtyas, 2015), which also found that Economic Incentives had a positive and significant effect on purchases. Economic Incentives are powerful motivators of human behavior in general (Thurau et al., 2004). According to the results of a questionnaire related to information about promos and purchase bonuses from Instagram, consumers perceive economic benefits from accessing information through Instagram, such as fruit prices, promos, and purchase discounts when purchasing products from Kojama Shop. Furthermore, consumers benefit from cost-efficiency when accessing information via Instagram social media, based on the results of questionnaires related to various questions asked about Kojama Shop fruit products via Instagram, which is more efficient and does not cost a lot. 
Consumers who want to buy products at Kojama Shop can access information through Instagram social media easily and anywhere to get a lot of information about Kojama Shop products without having to do a location survey, making it more efficient and not spending a lot of money. Kojama Shop sometimes provides free shipping to its customers every Friday and provides several discounts at certain times, so this is one of the economic benefits that Kojama Shop consumers can feel. Shimp (2007) believes that bonuses or price discounts play an important role in encouraging consumer behavior to try or buy the products or services offered. As a result, information about economic incentives such as free shipping and purchase discounts that consumers will receive when purchasing from Kojama Shop plays an important role in influencing someone to make a purchase decision.

4) The relationship between Helping the Company $\left(\mathrm{X}_{4}\right)$ and fruit purchases at the Kojama Shop (Y).

$\mathrm{H}_{0}$ : Helping the Company $\left(\mathrm{X}_{4}\right)$ has no significantimpact on fruit purchases at the Kojama Shop (Y).

$\mathrm{H}_{\mathrm{a}}$ : Helping the Company $\left(\mathrm{X}_{4}\right)$ has a significantimpact on fruit purchases at the Kojama Shop (Y).

$\mathrm{T}_{\text {count }}=6,058>\mathrm{t}_{\text {table }}=1,655(\mathrm{df}=145, \alpha=0,05)$. $\mathrm{H}_{0}$ is then rejected, while $\mathrm{H}_{\mathrm{a}}$ is accepted. As a result, the Helping the Company variable individually has a significant effect on the variable of purchasing fruit products at Kojama Shop. This result means that the stronger consumers' willingness or desire to spread positive information about Kojama Shop via Instagram social media, the more likely consumers or other potential customers will purchase fruit products from Kojama Shop. These findings are consistent with (Hasan and Setiyaningtyas, 2015) research, which found that assisting the company had a positive and significant impact on purchases. Consumers' willingness or desire to assist the manager in conveying information about fruit products at the Kojama Shop will be shaped by their positive and satisfying experiences with fruit products at the Kojama Shop. According to Ladhari et al (2008), the quality of service perceived by customers has an impact on satisfaction in terms of positive or negative emotions, and this has an impact on post-purchase behavior. Post-purchase behavior, such as assisting the company with publication, is in question. Information about Kojama Shop fruit products has been widely disseminated on Instagram, particularly through previous Kojama Shop consumer personal account posts. Consumers can get an overview of Kojama Shop's fruit products from these various posts. Consumers can also know and feel the wishes of others, ensuring that Kojama Shop is successful and well-known. The eWOM activity will almost certainly benefit the Kojama Shop manager as well. According to Chevalier and Mayzlin (2006), the number of online reviews or comments about a product or service indicates its popularity. Furthermore, the amount of information shared by someone is one factor that can assist others in making a purchasing decision (Chevalier and Mayzlin, 2006).

5) The relationship between Platform Assitance $\left(\mathrm{X}_{5}\right)$ and fruit purchases at the Kojama Shop (Y).

$\mathrm{H}_{0}$ : Platform Assisstance $\left(\mathrm{X}_{5}\right)$ has no significantimpact on fruit purchases at the Kojama Shop (Y).

$\mathrm{H}_{\mathrm{a}}$ : Platform Assistance $\left(\mathrm{X}_{5}\right)$ has a significantimpact on fruit purchases at the Kojama Shop (Y).

$\mathrm{T}_{\text {count }}=2,179>\mathrm{t}_{\text {table }}=1,655(\mathrm{df}=145$, $\alpha=0,05) . H_{0}$ is then rejected, while $H_{a}$ is accepted. As a result, the Platform Assistance variable individually has a significant effect on the variable of purchasing fruit products at Kojama Shop. These findings are consistent with Cahyono's (2016) research, which discovered that Platform Assistance had a positive and significant effect on purchase intention. Instagram makes it simple for users to connect with others in order to share information and experiences. Instagram is widely used as a social media marketing tool by businesses, one of which is Kojama Shop. Electronic Word of Mouth (eWOM) on Instagram can be considered successful. This is evidenced by the 121.000 followers of the @kojamashop account as of May 1, 2020, at 19.00. Followers of the @kojamashop account actively review, update, recommend, or simply share their experiences. According to research, Kojama Shop consumers actively use Instagram, with the majority of Kojama Shop consumers opening Instagram for more than 3 hours in a single day. According to Rizki's (2017) research, someone is said to be active on Instagram if they access Instagram for nearly an hour per day. Instagram's existence can lead to social interaction, which encourages the creation 
of eWOM. According to Rizki's (2017) research, someone is said to be active on Instagram if they access Instagram for nearly an hour per day. Instagram's existence can lead to social interaction, which encourages the creation of eWOM.

\section{Conclusion}

The factors forming Electronic Word of Mouth (eWOM) on the purchase of fruit products at Kojama Shop are Concern for Others, Expressing Positive Feelings, Economic Incentives, Helping the Company and Platform Assistance.

The results showed that:

a. Factors that influence Concern for Others on the purchase of fruit products at Kojama Shop is the strong concern of consumers in providing information and recommendations to others.

b. Factors that influence Expressing Positive Feelings on the purchase of fruit products at Kojama Shop is a positive impression on Kojama Shop products

c. Factors that influence Economic Incentives on purchasing fruit products at Kojama Shop are free shipping to consumers every Friday and discounts at certain times

d. Factors that influence Helping the Company on the purchase of fruit products at Kojama Shop is the willingness or desire of consumers to help the Kojama Shop.

e. Factors that influence Platform Assistance on purchasing fruit products at Kojama Shop are followers of the @kojamashop account actively reviewing, updating, and recommending products related to Kojama Shop.

\section{References}

Anastasia, A. \& Susana, U. 1997. Psychological Testing. New Jersey: Prentice Hall.

Asosiasi Penyelenggara Jasa Internet Indonesia. 2018. Penetrasi dan Perilaku Pengguna Internet Indonesia Survey 2018. Jakarta: Asosiasi Penyelenggara Jasa Internet Indonesia.

Augusty, F. 2006. Metode Penelitian Manajemen: Pedoman Penelitian untuk Skripsi, Tesis dan Disertasi Ilmu Manajemen. Semarang: Universitas Diponegoro.
Cahyono, F.D, Kusumawati, A., \& Kumadji, S. 2016. Analisis Faktor-Faktor Pembentuk Electronic Word of Mouth (eWOM) dan Pengaruhnya Terhadap Minat Beli (Survei pada Followers Akun Instagram @saboten_shokudo). Jurnal Administrasi Bisnis (JAB), 37 (1), 148-157.

Canhoto, A. I., dan Clark, M. 2013. Customer Service 140 Characters at a Time-The Users' Perspective. Journal of Marketing Management, 29(5/6), 522-544.

Chevalier, J., \& Mayzlin, D. 2006. The Effect of Word of Mouth on Sales: Online Book Reviews. Journal of Marketing Research, 43 (3), 345-354.

Erkan, I., dan Evans, C. 2016. The Influence of eWOM in Social Media on Consumers' Purchase Intentions: An Extended Approach to Information Adoption. Computers in Human Behavior, 61, 47-55.

Ghozali, I. 2012. Aplikasi Analisis Multivariate dengan Program IBM SPSS. Semarang: Universitas Diponegoro.

Harimurti, A. C., Sadeli, A. H., H.N. Utami, H. N., \& Mukti, G.W. 2016. Strategi Peningkatan Kinerja Atribut Produk Sayuran Melalui Pemasaran Online Dalam Upaya Meraih Kepuasan Konsumen. Jurnal Agrosains dan Teknologi, 1 (2), 4863.

Hasan, A., \& Setiyaningtyas, N. W. 2015. Pengaruh Electronic Word of Mouth pada Media Sosial Facebook terhadap Keputusan Berkunjung ke Desa Wisata Nglanggeran Gunung Kidul. Jurnal Media Wisata, 13 (1), 224- 238.

Huyen, T. T., dan Costello, J. 2017. Quality versus Quantity: An Investigation into Electronic Word of Mouth's Influence on Consumer Buying Intention. Journal of Promotional Communications, 5(2), 137155.

Janie, D. N. A. 2012. Statistik Deskriptif \& Regresi Linier Berganda dengan SPSS. Semarang: Semarang University Press.

Jeong, E. \& Soocheong, J. 2011. Restaurant Experiences Triggering Positive Electronic Word of Mouth (EWOM) Motivations. International Journal of Hospitally Management, 30 (1), 356-366. 
Jun, M., Yang, Z., and Kim D. 2004. Customers' Perceptions of On; in Shopping Service Quality and Their Satisfaction", International Journal of Quality \& Reliability Management, 21 (8), 817-840.

Kim, E., Sung, Y., dan Kang, H. 2014. Brand Followers' Retweeting Behavior on Twitter: How Brand Relationships Influence Brand Electronic Word of Mouth. Computers in Human Behavior, $37,18-25$.

Ladhari, R., Brun, I., \& Morales, M. 2008. Determinants of Dining Satisfaction and Postdining Behavioral Intentions. International Journal of Hospitality Management, 27 (4), 563-573.

Pergub Prov. DKI Jakarta. No 114. 2019. Tentang Upah Minimum Sektoral Provinsi Tahun 2019.

Rachmalika, B.R.A., Kumadji, S., \& Mawardi, M.K. 2015. Analisis Faktor- Faktor Pembentuk Electronic Word of Mouth (eWOM) dan Pengaruhnya Terhadap Keputusan Pembelian pada Restoran Hakata Ikkouxha Jakarta. Jurnal Administrasi Bisnis (JAB), 25 (1), 1-10.

Riduwan \& Akdon. 2013. Rumus dan Data dalam Aplikasi Statistika. Bandung: Alfabeta.

Rizki, A.I. 2017. Hubungan Antara Intensitas Penggunaan Media Sosial Instagram dengan Harga Diri. Skripsi. Universitas Muhammadiyah Surakarta, Surakarta.

Sari, V.M. 2012. Pengaruh Electronic Word of Mouth (EWOM) di Sosial Media Twitter Terhadap Minat Beli Konsumen (Studi Pada Restoran Holycowsteak). Skripsi. Depok: Universitas Indonesia.

Sakti, O. A. F. 2018. Hubungan Karakteristik Konsumen dengan Faktor yang Dipertimbangkan dalam Pembelian Sayuran Organik di Convenience Store Bogor. Skripsi. IPB.

Shimp, T. A. 2007. Advertising, Promotion, and Other Aspects of Integrated Marketing Communications (Seventh Edition). Thomson South-Western: USA.

Sugiyono. 2018. Metode Penelitian Kuantitatif, Kualitatif, dan Kombinasi (Mixed Method). Bandung: Alfabeta.
Thurau, H., Thorsten., Gwinner K. P., Walsh G., \& Glemrel D. D. 2004. Electronic Word of Mouth Via Consumer Opinion Platforms: What Motivates Costumer to Articulate Themselves on The Internet. Journal of Interactive Marketing, 18 (1), 38-52.

Turban, E. and Lee, M.K.O. 2001. A Trust Model for Consumer Internet Shopping. International Journal of Electronic Commerce, 6 (1), 75-91.

Wien, A. H., \& Olsen, S. O. 2014. Understanding the Relationship between Individualism and Word of Mouth: A Self Enhancement Explanation. Psychology and Marketing, 31 (6), 416-425. 